PART III

ACTIVISM, EXHIBITION'S POLITICS

AND

EUROPEAN UNION'S POLITICS 


\title{
Porcelain Fear
}

\section{Tatjana Greif}

holds a PhD in Archaeology, University of Ljubljana, Slovenia,

and is a LGBT activist, publicist and editor

(tatjana.greif@guest.arnes.si)

\begin{abstract}
:
The article is a short consideration about different faces of fear and its abuse for suppressing the society - about the political fear from non-obedient citizens, the fear of citizens from corporative state, the fear of people from other people, and between people. LGBT people are both representing fear to the others and they suffer the phobia of the society. The article is about how in the Balkans a small porcelain figurine can become a threat just with a hint of lesbianism.
\end{abstract}

Key words: capitalism, church-state, LGBT, ex-YU, fear management

\begin{abstract}
Of course the Nazis were wrong to hate the Jews. But their hating the Jews was not without the cause. It's just that the cause wasn't real. The cause was imagined. The cause was fear.... Let's think of another minority. One that can go unnoticed if it needs to. There are all sorts of minorities, blonds for example ... or people with freckles. But a minority is only thought of as one when it constitutes some kind of threat to the majority. A real threat or an imagined one ... And therein lies the fear. If that minority is somehow invisible than the fear is much greater. That fear is why the minority is persecuted. And, so you see there always is a cause. The cause is fear. Minorities are just people. People like us. ... Fear after all is our real enemy. Fear is taking over our world. Fear is being used as a tool of manipulation in our society. It's how politicians peddle policy. It's how Madison Avenue sells us things we don't need. Think about it. The fear of being attacked. The fear of threat there are Communists lurking around every corner. The fear that some little Caribbean country that doesn't believe in our way of life poses a threat to us. The fear that black culture may take over the world. The fear of Elvis Presley's hips...
\end{abstract}

From the film "A Single Man" based on a novel by Christopher Isherwood

That is how gay professor Falconer explains fear to his students in a Hollywood film "A Single Man" based on a novel by Christopher Isherwood. It is a strikingly bizarre and vulgar story of a painful truth hidden within this quite simple definition of fear. The story in the novel and the film takes place during one day in 1962 in Southern California. Just a few years later, the US government began to demonstrate certain fear of John Lennon's public appearances. At the time, the former Beatle and peace activist came to the States with his partner Yoko Ono. Lennon and Ono befriended Bobby Seale, Jerry Rubin, Abbie Hoffman and Angela Davis, members of the Black Panthers' movement and radical activists. President Nixon and FBI's head Edward Hoover decided to deport Lennon back to Europe. The 1980s brought the assassination of Lennon and the end of Black Panthers. Some of them later on became Republicans, businessmen or author of cookbooks.

The universal phenomenon of fear was used by the military couple of state and church to develop "fear management" in order to oppress and control society. Fear as such is fundamentally the same and the technologies of its abuse may vary.

Thinking of a situation of LGBT people and their lives in the states of former Yugoslavia I am actually thinking of fear - the very same fear described above, as the quote says: "if that minority is somehow invisible than the fear is much greater." It is the fear of dominant mainstream majority towards non dominant marginal minority.

Focusing on former Yugoslavia and the new states that issued from the Federation, placed on what was once a magnificent stage, and considering the war and enormous political change that happened in last two decades, I would still claim there is nothing really different here from what takes place in the West. Once multicultural and multilingual one party regime is today part of uniform capitalist world order; a one party regime, too. Only this time a global one. 
In former Yugoslav Socialist Republic of Slovenia homosexuality was decriminalized in 1976 as part of a federal law reform, and followed by Croatia in 1977.

Other republics introduced decriminalization in the 1990s, Serbia in 1994, Macedonia and Bosnia in 1996. After the fratricidal and sororicidal - why nobody is using that word? - war in the 1990s and the formation of new states in the ashes of the old one, other former SFRJ republics decriminalized homosexuality too and adopted different jurisprudence on human rights.

Nowadays, protective legislation for LGBT people exists, in different size and content, but its implementation is poor. And, if there is legal protection and if there is democracy, if there is such a mental progress - how come that there is still enormously high level of intolerance and homophobia? In comparison with the 1960s and earlier, it is so that homosexuals and lesbians, who were criminalized before, even imprisoned, are now not criminalized any more by the law. But they are criminalized by the society - hostile attitudes, archaic patriarchal machismo, social distance, intolerance and homophobia remain. Strong and persistent as ever.

And in current situation the reality of LGBT people is not created by LGBT people and nor by the movement. It is created by political absence of-will to ever change the status quo. And it is created by the digitalized slave of politics and the media. Media absolutism, news hierarchy, filtered informational overload - all this produces a homophobic culture. But the public is not like archaeology - excavating the artifacts with precise stratigraphical method, discovering and unearthing fragments. The public is just absorbing, "sucking" and consuming the bigger and bigger, the more and more, disguised manipulative information chaos. The public is not using scientific excavation method for gathering real information - it just hears, digests and walks away. And it is a paradox how easy it is to upset the public, to mobilize the politics, to attract media attention.

Recently two small porcelain figurines depicted on a theater poster promoting a lesbian play "Fine, Death Girls" deeply upset Croatian society, both Catholics and Muslims, believers and non-believers, but also politicians. The image of two holly Virgin Maries, lovingly embracing one another across the shoulder, in shining blue-and-white porcelain - that was too much of a stress for religious and political leaders. This theater poster with the image of a double Virgin Mary, a loving female couple was offensive for two different religions, historically in antagonist relationship, now supporting each other. How about that?

The media was only happy to publish an open letter written by mufti Aziz ef. Hasanović who was seriously concerned about the poster, claiming that the image on the poster was offensive for Muslims even if made direct reference to Catholic Christianity. Mufti said that both Catholicism and Islam equally respect "Mejrem or virgin Mary the mother of Christ." He said that in the "past times" due to the "low level of civilization" the offense of religious symbols was acceptable, but the trend to offense religious filings is now growing under the cover of free speech. I wonder which "past times" he was referring to. As a reaction to such intervention a second poster appeared in which two virgins are depicted wearing burqa. Archbishop Bozanić took a turn and spoke against "painful political dictatorship and ideological totalitarism" about harmful and dangerous "re-education of children and youth... forbidding them free choice and honesty."

After the poster for the theater show was ostracized and removed from the public eye, many artists protested. Theater actors, and intellectuals and the whole ensemble of Gavela theatre where the two virgins Maries incident occurred, condemned the act of religious and political censorship of art. Only one politician supported them, the mayor of the city of Rijeka, who invited the show to his city.

Not coincidently similar, the church in Slovenia raised a huge scandal in the end of the 1990s, when a small electro punk group Strelnikoff from Celje realized their album Bitchcraft with a cover illustrated with a depiction of virgin Marry of Brezje holding a rat instead of baby Jesus.

In July 2013 a small group of gays and lesbians with a few supporters organized the first ever pride parade in a small town of Budva on the Adriatic Coast in Montenegro; the regional scenario was the same as in Belgrade, Split or Zagreb before...flying stones, bricks, violence, wounded participants, assaults and miserable shame. A female professor, who gave a speech to support the Pride, commented: "If only our fellow citizens were so resistant and aggressive in cases of corruption, political fraud and ideological violence in this country..." 
How can a public like that, how can average citizens recognize that there is a connection between them and the "others?" How can they understand the connections amongst different oppressions facing different historically underprivileged communities, repressed groups, non-whites, elders, ethnic minorities, migrants, refugees, low-income people, people with disabilities, sex workers, gays and lesbians, Roma, of different class? How could they see and identify, let alone confront any forms of oppression?

Humans, human society and human rights are under uniform capitalist world order, where political and media discourse are market-conditioned, and in which citizen's rights, genders and sexualities are produced and reproduced trough libidinization of market commodities. In this uniform capitalist world order, bodies of LGBT citizens are - fit or unfit part of political economy of the body, having their market value in multiple markets. The reasoning behind capitalist production is colonizing sexual exchanges, sexual politics and social discourses. The relationship between sexual politics and capitalism in global hyper marketplaces is fascinating. Inseparable links between politics and sexuality make the intention of political sphere to control LGBT people more militant. Homosexual people are not practicing heteronormative reproductive sex which brings capitalist state and capitalist church profits. As such they represent a threat and source of fear of profit loss. Partly this matter can easily be solved by giving LGBT people marriage and family rights, equal or similar to heterosexual citizens, by making them "normal" and obedient citizens that have been commodified. But this is only one type of a solution. Namely, not all LGBT people are interested in getting married, giving their bodies at disposal to the state and capital or fitting into the norm.

And what is strategic basis for the discussion of sexual rights in Eastern Europe and the Balkans in the context of present and future of commoditization of sexual relationships, in which our bodies are actively involved? Who is in capacity to achieve social change for those who are unfit or unwilling to give their bodies for market economy reframed for profit making? Is it the LGBT movement or individuals? Nobody? Who will survive the collapse of the centuries? This question seems to be utopian multiple hypothesis.

Dr. Tatjana Greif has been active for several decades with human rights in the sphere of gender issues and sexual orientation. For several years she coordinates the lesbian group ŠKUC -LL in the association ŠKUC, Ljubljana, Slovenia. Since 2004, she is the chief editor of the book series ŠKUC Vizibilija, and as well she is member of the editorial boards of several magazines and journals (Delta, Journal for Critique of Science, Lesbo ). Especially valuable is her role as promoter of non-governmental organizations for the legalization of same-sex relationships, which led to the regulation of the status of same-sex couples or to the adoption of the registration of same-sex partnerships in 2005. 